\title{
HALOMETHANOCOCCUS DOII GEN. NOV., SP. NOV.: AN OBLIGATELY HALOPHILIC METHANOGENIC BACTERIUM FROM SOLAR SALT PONDS
}

\author{
IDA K. YU AND FUJIO KAWAMURA ${ }^{1}$ \\ Department of Biochemistry and Biophysics, University of California, \\ Davis, California 95616, U.S.A.
}

(Received October 8, 1986)

\begin{abstract}
A new obligately halophilic methanogenic bacterium, strain IY-1, was isolated from a salt water pond near San Francisco Bay. The bacterial cells are pleomorphic cocci, $0.3-1.5 \mu \mathrm{m}$ in diameter and require a minimum of $10 \%$ salt $(1.8 \mathrm{M} \mathrm{NaCl})$ for growth. Optimum growth occurs at $17.5 \%$ salt $(3.0 \mathrm{M} \mathrm{NaCl})$. Methanogenic substrates included methylamines and methanol, but not formate, $\mathrm{H}_{2} / \mathrm{CO}_{2}$, or acetate. Acetate and rumen fluid were required for cell growth. Growth occurred throughout the temperature range 5 to $45^{\circ} \mathrm{C}$ with an optimum at $35^{\circ} \mathrm{C}$. The $\mathrm{pH}$ optimum for growth was 6.8 and cell growth occurred throughout the $\mathrm{pH}$ range 5.8 to 7.6. Growth in complex medium had a doubling time of $9 \mathrm{hr}$ at $37^{\circ} \mathrm{C}$. The cells were not easily ruptured by mechanical means and were not sensitive to penicillin $G$, cycloserine, or rifampicin. Bacterial colonies formed on solid medium were white and circular to oval in shape, with irregular margins. Electron micrographs of ultrathin sections revealed homogeneous granular ribosome-like particles and a thin cell wall, but the membrane could not be observed by the standard Kellenberger's fixation method. The DNA base composition of the isolate was $43.2 \mathrm{~mol} \%$ guanine plus cytosine. We propose Halomethanococcus gen. nov. as the genus and Halomethanococcus doii sp. nov. as the type species for this novel bacterium. Strain IY-1 is the type strain (ATCC 43619).
\end{abstract}

Evidence of methanogenesis has been reported in hypersaline environments. SHOKES et al. (1) found high concentrations of methane in the brine and sediment waters of the anoxic Orea Basin in the Gulf of Mexico. Oremland et al. (2) reported

Address reprint requests to: Dr. I. K. Yu, Department of Biochemistry and Biophysics, University of California, Davis, California 95616, U.S.A.

${ }^{1}$ Present address: Institute of Applied Microbiology, The University of Tokyo, Bunkyo-ku, Tokyo 113, Japan. 
methane in Great Salt Lake sediments. Recently many new genera of marine methanogenic bacteria have been described(3-6). Two moderately halophilic methanogens have been reported (7-9).

This report describes a new halophilic methanogenic bacterium isolated from a solar brine pond near San Francisco Bay. This isolate differs from previously reported halophilic methanogens in its ability to grow in extremely high salt conditions, its DNA base composition, and its surface antigen properties.

\section{MATERIALS AND METHODS}

Source of inoculum. Sediment from a brine pond at the Leslie Salt Co. near San Francisco Bay, CA, U.S.A. was collected under a 1-1.5 inch layer of crystalline salt. The sample was transported in a screw-capped glass bottle, filled to capacity.

Culture medium. Complex medium was prepared using salt pond water. Added to each liter of pond water were: $\mathrm{NH}_{4} \mathrm{Cl}, 1.0 \mathrm{~g} ; \mathrm{K}_{2} \mathrm{HPO}_{4} \cdot 3 \mathrm{H}_{2} \mathrm{O}, 0.4 \mathrm{~g}$; $\mathrm{KH}_{2} \mathrm{PO}_{4} \cdot 3 \mathrm{H}_{2} \mathrm{O}, 0.4 \mathrm{~g} ; \mathrm{MgCl}_{2} \cdot 6 \mathrm{H}_{2} \mathrm{O}, 0.1 \mathrm{~g}$; yeast extract, $2.0 \mathrm{~g}$; trypticase, $2.0 \mathrm{~g} ; \mathrm{Na}$ acetate $\cdot 3 \mathrm{H}_{2} \mathrm{O}, 2.0 \mathrm{~g} ; 1 \%$ rumen fluid; trimethylamine hydrochloride, $4.7 \mathrm{~g}$; resazurin, $0.001 \%$. A relatively more defined medium was composed of the following additions per liter of Milli-Q deionized water: $\mathrm{K}_{2} \mathrm{HPO}_{4} \cdot 3 \mathrm{H}_{2} \mathrm{O}, 0.4 \mathrm{~g}$; $\mathrm{KH}_{2} \mathrm{PO}_{4} \cdot 3 \mathrm{H}_{2} \mathrm{O}, 0.4 \mathrm{~g} ; \mathrm{KCl}, 3.8 \mathrm{~g} ; \mathrm{MgCl}_{2} \cdot 6 \mathrm{H}_{2} \mathrm{O}, 7.9 \mathrm{~g} ; \mathrm{MgSO}_{4} \cdot 7 \mathrm{H}_{2} \mathrm{O}, 6.0 \mathrm{~g}$; $\mathrm{NH}_{4} \mathrm{Cl}, 1.0 \mathrm{~g} ; \mathrm{CaCl}_{2} \cdot 2 \mathrm{H}_{2} \mathrm{O}, 4.0 \mathrm{~g} ;\left(\mathrm{NH}_{4}\right)_{2} \mathrm{Fe}\left(\mathrm{SO}_{4}\right)_{2}, 0.01 \mathrm{~g} ; \mathrm{NaCl}, 150 \mathrm{~g} ; \mathrm{Na}$ acetate $3 \mathrm{H}_{2} \mathrm{O}, 2.0 \mathrm{~g}$; trimethylamine hydrochloride, $4.7 \mathrm{~g}$; resazurin, $0.001 \% ; 1 \%$ rumen fluid. Cells grew better in the complex medium than in the more defined medium. Cells were stored under anaerobic conditions in complex medium.

The medium was boiled under $\mathrm{O}_{2}$-free $\mathrm{N}_{2}$, cooled and adjusted to $\mathrm{pH} 6.8$ with $3 \mathrm{~N} \mathrm{HCl}$. Two percent Bacto-agar (Difco-certified, Difco Laboratories, U.S.A.) was used for the solid complex medium. The complex medium was dispensed under $\mathrm{N}_{2}$ into serum vials or culture tubes, stoppered, and sterilized by autoclaving. Sterile, anaerobic stock solutions of $3 \% \mathrm{Na}_{2} \mathrm{~S} \cdot 9 \mathrm{H}_{2} \mathrm{O}, 5 \% \mathrm{NaHCO}_{3}$, and $3 \%$ cysteine- $\mathrm{HCl}$ were prepared; prior to inoculation they were added to the media to yield final concentrations of $0.001,0.02$, and $0.003 \mathrm{M}$, respectively. The final $\mathrm{pH}$ of the medium was 7 to 7.2 .

Enrichment and isolation. Approximately $3 \mathrm{ml}$ of sediment was added to $50 \mathrm{ml}$ of complex culture medium in a $160-\mathrm{ml}$ capacity serum vial $(10,11)$. Penicillin G $(3 \mathrm{mg} / \mathrm{ml})$ was added to the culture medium and the culture was incubated at $37^{\circ} \mathrm{C}$. Methane production was measured daily until it reached a peak at 10 days. At that time, serial ten-fold dilutions of the enrichment culture were inoculated into roll tubes and incubated at $37^{\circ} \mathrm{C}$. Methanogenic colonies presumptively identified by epifluorescence microscopy (12) occurred in all dilutions up to $10^{-8}$.

Methane determination. Methane was determined by gas chromatography on a Varian Series 1440 GC equipped with flame ionization detector. The column was $1 / 20.3 \times 91.5 \mathrm{~cm}$ teflon, packed with Porapak Q (Carle Products for Chromatography, Loveland, Co., U.S.A.). Helium served as the carrier gas at a rate 
of $30 \mathrm{ml} / \mathrm{min}$. Oven and injection port temperatures were 120 and $70^{\circ} \mathrm{C}$, respectively. Methane production was calculated by plotting versus time, the natural logarithm of the sum of the accumulated methane.

Determination of DNA base composition. Cells were broken by mechanical shaking using a Bronwell Homogenizer. DNA was purified by the method of BLIN and STAFFORD(13). DNA buoyant density was determined by centrifugation through a cesium chloride gradient in a Beckman Model E centrifuge. $\mathrm{Mol}^{\%}$ of guanine plus cytosine content $(\mathrm{G}+\mathrm{C})$ of DNA was calculated by the method of SCHILDKRAUT et al. (14).

Electron microscopy. Mid-exponential phase cells were fixed with $4 \%$ glutaraldehyde including $9 \% \mathrm{NaCl}$. Cells were then left in $2.5 \%$ ruthenium red for $15 \mathrm{~min}$. Kellenberger's method was used for prefixing.

\section{RESULTS}

A halophilic methanogenic bacterium, strain IY-1, was isolated from a 10-day old enrichment culture inoculated with a solar salt pond sediment. On solid medium, surface colonies were circular to oval in form and white in color with irregular margins. The colonies averaged $2 \mathrm{~mm}$ in diameter after 4 weeks of incubation and exhibited a bright blue fluorescence when viewed with the fluorescence microscope. Cells were lysed in $0.005 \%$ sodium dodecyl sulfate or in $0.001 \%$ Triton X-100. In liquid medium, individual cells of the halophile were irregular cocci with an average diameter of $0.3-1.5 \mu \mathrm{m}$ (Fig. 1). Cells were gram negative, nonmotile, and in electron micrographs of ultrathin sections very thin cell walls appeared but no flagella. The most striking feature of the thin sections was the homogeneity of the ribosome-like granules, which were $2-3 \times$ smaller than the usual procaryotic ribosomes (Fig. 2).

The optimal concentration of the brine for methanogenesis was $17.5 \%(3.0 \mathrm{M}$ $\mathrm{NaCl}$ ) and the minimal salt requirement was $10 \%(1.8 \mathrm{M} \mathrm{NaCl})$ (Fig. 3).

The optimal growth temperature of the isolate was $35^{\circ} \mathrm{C}$ (Fig. 4). Growth

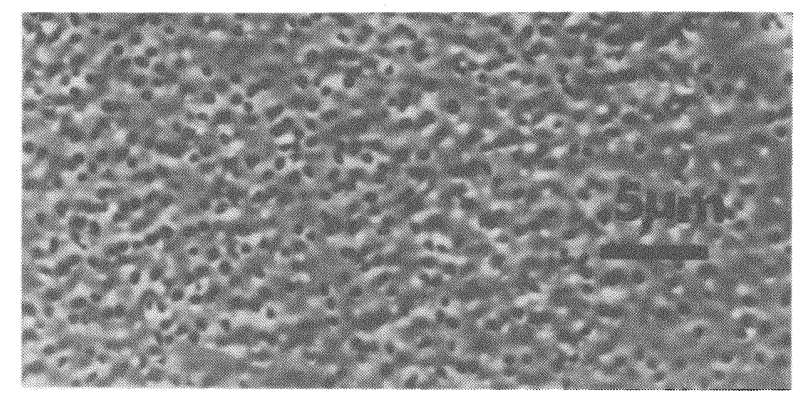

Fig. 1. Phase contrast photomicrograph of a disrupted, agar-mounted, halophilic, and methanogenic bacterium colony of strain IY-1 releasing irregular cocci. Note the pleomorphic nature of the cells. 


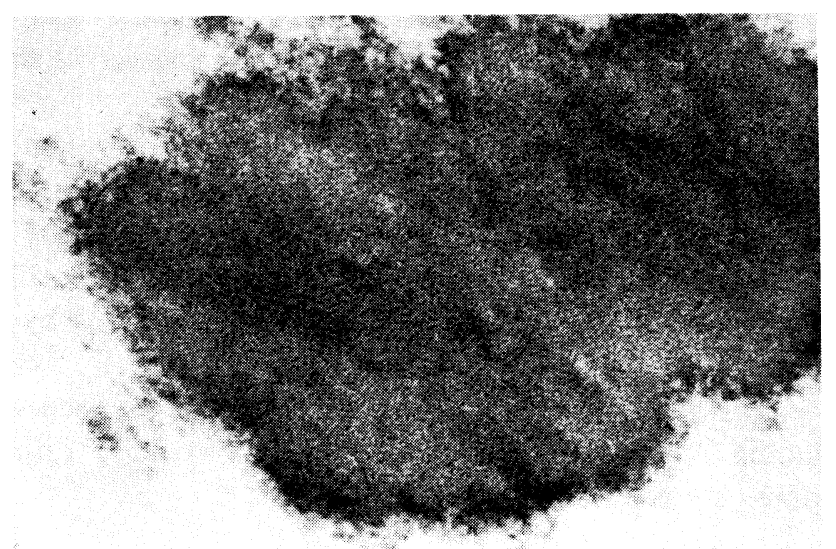

Fig. 2. Electron micrograph of an ultrathin section $(\times 300,000)$ of a halophilic, methanogenic bacterium, strain IY-1. Note the presence of regular ribosome-like structures (by Dr. Jack Pangborn).

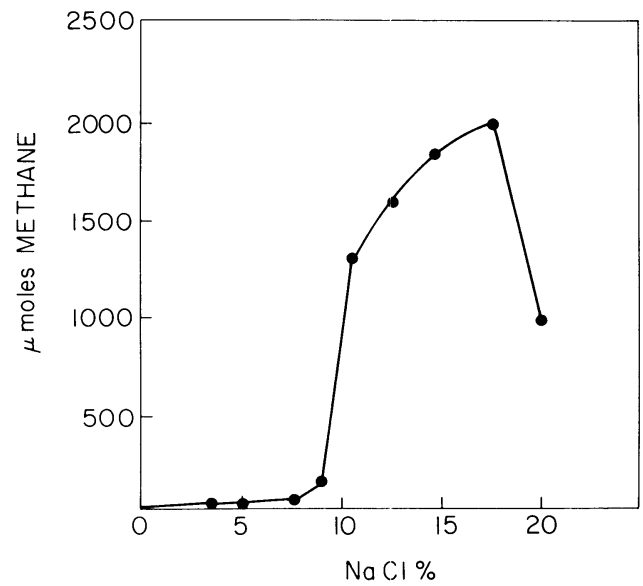

Fig. 3. Salt concentration versus production of methane by strain IY-1. The cells were grown at $35^{\circ} \mathrm{C}$ in complex medium containing trimethylamine.

occurred within a broad temperature range from 5 to $45^{\circ} \mathrm{C}$ and throughout the $\mathrm{pH}$ range of 5.8-7.6 with an optimum at 6.8 (Fig. 5).

Excellent growth and methane production occurred in complex brine medium containing trimethylamine (Fig. 6) $\mathrm{H}_{2} / \mathrm{CO}_{2}$ was not utilized as a substrate. The generation times calculated from exponential methane generation of trimethylamine was $9 \mathrm{hr}$. In defined medium the generation time was slower and required rumen fluid as growth factor(s) (no shaking was required). Concentrations of $3,000 \mu \mathrm{g} / \mathrm{ml}$ of penicillin $\mathrm{G}, 450 \mu \mathrm{g} / \mathrm{ml}$ of cycloserine, and $200 \mu \mathrm{g} / \mathrm{ml}$ of rifampicin did not inhibit growth or methanogenesis by the bacterium. 


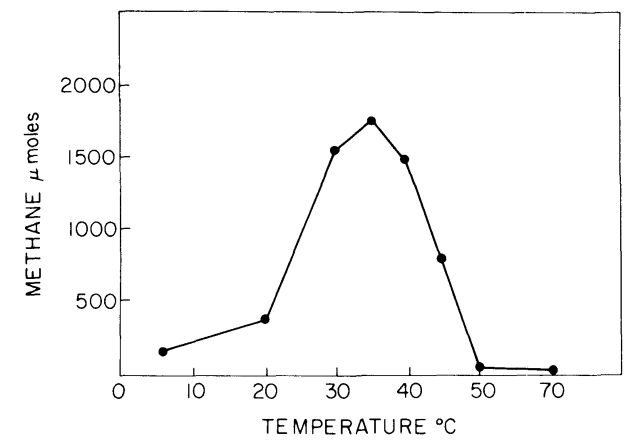

Fig. 4

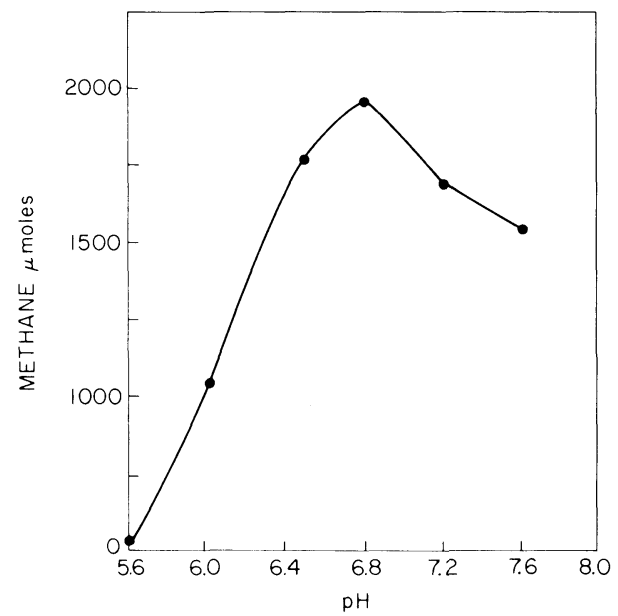

Fig. 5

Fig. 4. Methane production by strain IY-1 as a function of temperature. The cells were grown in complex medium containing $15^{\circ}{ }_{0} \mathrm{NaCl}$ and trimethylamine.

Fig. 5. Effect of $\mathrm{pH}$ on methane production by strain IY-1. The cells were grown at $35 \mathrm{C}$ in complex medium containing $15^{\circ}, \mathrm{NaCl}$ and trimethylamine.

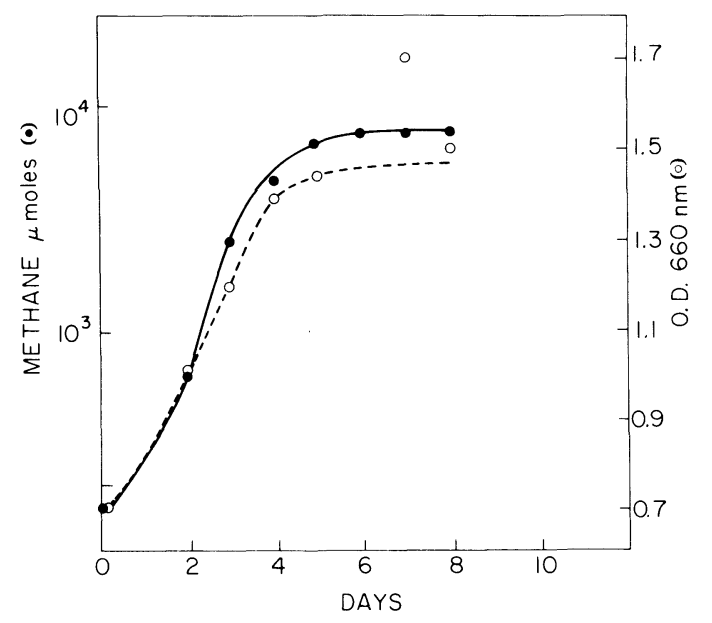

Fig. 6. Growth curve for strain IY-1. Cells were grown in complex medium containing $15 \% \mathrm{NaCl}$ and trimethylamine at $35 \mathrm{C}, \mathrm{pH} 6.8$. The curve was plotted as time versus the sum of the accumulated methane.

The antigenic fingerprint data obtained by the indirect immunofluorescence (IIF) technique (15) of this halophilic methanogen were negative with 23 isolated methanogens: (1 Methanobacterium bryantii MoHG; 2 Methanobacterium bryantii $\mathrm{MoH} ; 3$ Methanobacterium formicicum MF; 4 Methanobacterium ruminantium M1; 
5 Methanobacterium thermoautotrophicum $\mathrm{GC1} ; 6$ Methanobacterium thermoautotrophicum H; 7 Methanobrevibacter arboriphilus AZ; 8 Methanobrevibacter arboriphilus DC; 9 Methanobrevibacter arboriphilus DH1; 10 Methanobrevibacter smithii AL1; 11 Methanobrevibacter smithii PS; 12 Methanococcus mazei C6; 13 Methanococcus vannielii SB; 14 Methanococcus voltae PSv; 15 Methanogenium cariaci JR1c; 16 Methanogenium marisnigri JR1m; 17 Methanomicrobium mobile BP; 18 Methanosarcina barkeri 227; 19 Methanosarcina barkeri MS; 20 Methanosarcina barkeri R1M3; 21 Methanosarcina barkeri W; 22 Methanosarcina TM1; 23 Methanospirillum hungatei JF1).

The base composition as determined by buoyant density measurements of purified DNA from the halophilic methanogenic bacterium was $43.2 \pm 1 \mathrm{~mol} \%$ $\mathrm{G}+\mathrm{C}$.

\section{DISCUSSION}

The new isolate reported in this work is an example of an extremely halophilic methanogenic bacterium. It required a minimum of $10 \% \mathrm{NaCl}$ for growth and was able to produce methane in up to $20 \% \mathrm{NaCl}$. Optimum growth based on methanogenesis occurred at $17.5 \% \mathrm{NaCl}$.

Methanogenic substrates include methylamine and methanol, but not formate, $\mathrm{H}_{2} / \mathrm{CO}_{2}$, or acetate. However, acetate and rumen fluid were required for cell growth in both the complex and defined media. This is similar to the metabolic characteristics reported for Methanogenium cariaci(4), and Methanoplanus limicola (5). The isolate grew at $5^{\circ} \mathrm{C}$ which is atypical for methanogens in general. Furthermore, it exhibited an unusually broad temperature range of $5-45^{\circ} \mathrm{C}$.

No cell membrane appeared, even at a magnification of $330,000 \times$. A most striking feature of the cell that has not been observed in other methanogens was the homogeneous ribosome-like granules that were distributed throughout the cell. The cells were difficult to rupture by mechanical means, which is similar to the condition in Halococcus morrhuae(16). Cells of the halophilic methanogen were irregular cocci. Colonies were white in color, pleomorphic with irregular margins. Under epifluorescence, the colonies appeared bright blue at $420 \mathrm{~nm}$.

The DNA base composition of the isolate in this study was $43.2 \pm 1 \% \mathrm{G}+\mathrm{C}$. The other reported halophilic methanogens have a $\mathrm{G}+\mathrm{C}$ composition of $48.5 \%(8)$ and $41 \pm 1 \%$ (7). The surface antigen of this new isolate had no cross reaction with antibodies against 23 other strains of methanogens.

Strain IY-1 is similar in some characteristics to a number of recently isolated methanogens: Methanolobus tindarius(6), Methanococcoides methylutens (17), Methanococcus halophilus (16), "Halomethanococcus mahi" (8), and strain SF1 (7). All of the microorganisms are gram negative, irregular cocci with thin cell walls. Methylamines and methanol are the only substrates utilized for growth and methanogenesis. Thus, these five microorganisms represent a distinct group within the methanogenic bacteria. 
Table 1. Properties of halophilic methanogens.

\begin{tabular}{|c|c|c|c|c|c|c|}
\hline Species & $\begin{array}{l}\mathrm{Mol} \% \\
\mathrm{G}+\mathrm{C}\end{array}$ & $\begin{array}{c}\text { Temp. } \\
\text { optimum } \\
\left({ }^{\circ} \mathrm{C}\right)\end{array}$ & $\begin{array}{c}\mathrm{pH} \\
\text { optimum }\end{array}$ & $\begin{array}{l}\text { Optimum, } \\
\text { minimum } \\
\mathrm{NaCl} \text { for } \\
\text { growth }\end{array}$ & $\begin{array}{l}\text { Obligate } \\
\text { organic } \\
\text { factors } \\
\text { for growth }\end{array}$ & Refs. \\
\hline 1. Halomethanococcus doii & $43 \pm 1$ & $35-37$ & $6.6-7.2$ & $3.0,1.8$ & $\begin{array}{l}\text { rumen fluid, } \\
\text { acetate }\end{array}$ & \\
\hline 2. "Halomethanococcus mahi" & 48.5 & $35-37$ & $7.4-7.6$ & $2.1,0.5$ & N.R. & 8 \\
\hline 3. Strain SF1 & $42 \pm 1$ & $40-45$ & $6.8-8.7$ & $2.1,0.8$ & $\begin{array}{l}\text { rumen fluid, } \\
\text { or yeast } \\
\text { extract }\end{array}$ & 7 \\
\hline 4. Methanococcus halophilus & $41.9-43.1$ & $25-36$ & $6.5-7.4$ & $1.1,0.27$ & N.R. & 9 \\
\hline 5. Methanococcoides methylutens & 42 & $30-35$ & $7.0-7.5$ & $0.3,0.2$ & none & 17 \\
\hline
\end{tabular}

All of these strains and species were morphologically irregular cocci, used methylamines and methanol as methanogenic substrates for growth, were not motile, and were Gram negative. N.R.: not reported.

Strain IY-1 differs from all the previous isolates in salt requirement, temperature range, and its antigenic immunofluorescence serotyping. The minimum and maximum salt requirements for growth are 1.8 and $3.6 \mathrm{M}$, respectively. This places strain IY-1 in the extreme halophiles, and the others are moderate halophiles (Table 1). It can carry out methanogenesis at 5 to $45^{\circ} \mathrm{C}$ exhibiting an unusually broad temperature range. Growth at $5^{\circ} \mathrm{C}$ is atypical for methanogens in general. There is no antigenic relationship between strain IY-1 and the members of the families Methanobacteriaceae, Methanomicrobiaceae, and Methanosarcinaceae as indicated by indirect immunofluorescence serotyping (15). Therefore we recommend that a new genus Halomethanococcus gen. nov. be created.

Description of Halomethanococcus Yu and Kawamura gen. nov.

(Hal. o. me. tha. no. coc'cus Gr. n. hals, halos the sea, salt; M. L. n. methanum methane; Gr. n. coccus a berry; M. L. masc. n. Halomethanococcus the salt-methane coccus)

Cells: Gram negative, pleomorphic cocci $0.3-1.5 \mu \mathrm{m}$ in diameter, occurring singly, or in small irregular clumps, non-motile, thin cell wall.

Anaerobe: Obligate anaerobe.

Salt requirement: Minimum $1.8 \mathrm{M} \mathrm{NaCl}$ required for growth. Can grow up to $3.6 \mathrm{M} \mathrm{NaCl}$.

Substrates: Methylamines and methanol. Methanogenic.

Temperature range: 5 to $45^{\circ} \mathrm{C}$.

$\mathrm{pH}$ range for growth: 6 to 8 .

The type species of the genus Halomethanococcus is $H$. doii sp. nov. 
Description of Halomethanococcus doii Yu and Kawamura sp. nov.

(doii of Doi, named for R. H. Doi, a scientist who has contributed to microbiology)

Agar colonies: White, circular to oval in shape with irregular margins.

Sodium chloride requirement: $3.0 \mathrm{M} \mathrm{NaCl}$ for optimum growth.

Optimum temperature: Between $35-37^{\circ} \mathrm{C}$.

Optimum pH: pH 6.8 .

Growth factor requirements: Rumen fluid, acetate.

DNA composition $(\mathrm{G}+\mathrm{C} \% \mathrm{~mol}): 43.2 \pm 1 \%$.

Ultrathin section: Homogeneous granular ribosome-like particles.

Source: Evaporated salt water pond near San Francisco Bay.

IY-1 is designated as the type strain (ATCC 43619 monotype). Cell morphology, aerobiosis, and substrates for methane production are given in the description of the genus.

We thank Dr. Danny Wong and Alice Henin for excellent assistance in the preparation of this manuscript, Joanne Tredick for determining the buoyant density of the purified DNA, Jack Pangborn for preparing the electron micrographs, Drs. E. Conway de Macario and M. J. Wolin for performing the immunofluorescence reactions and Dr. Paul Baumann for helpful criticisms of the manuscript. This research was supported in part by National Science Foundation Grant PCM 84-04238.

\section{REFERENCES}

1) R. F. Shokes, P. K. Trabant, B. J. Presley, and D. F. Reid, Science, 196, 1443 (1977).

2) R. S. Oremland, L. Marsh, and D. J. DeoMarais, Appl. Environ. Microbiol., 43, 462 (1982).

3) J. B. Jones, B. Bowers, and T. C. Stadtman, J. Bacteriol., 130, 1357 (1977).

4) J. A. Roemesser, R. S. Wolfe, F. Mayer, E. Spiess, and A. W. Maujruschat, Arch. Microbiol., 121, 147 (1979).

5) G. Wildgruber, M. Thomm, H. Kongi, K. L. Theodor, and K. O. Stetter, Arch. Microbiol., 132, 31 (1982).

6) H. Konig and K. O. Stetter, Zbl. Bakt. Hyg. 1 Abt., 34, 1 (1982).

7) I. M. Mathrani and D. R. Boone, Appl. Environ. Microbiol., 50, 140 (1985).

8) J. R. Paterek and P. H. Smith, Appl. Environ. Microbiol., 50, 877 (1985).

9) T. N. Zhilina and V. V. Kevbrin, Mikrobiologiya (U.S.S.R.), 54, 93 (1985).

10) L. Baresi, R. A. Mah, D. M. Ward, and I. R. Kaplan, Appl. Environ. Microbiol., 36, 186 (1978).

11) J. B. ZeIKus, In The Biology of Methanogenic Bacteria, American Society for Microbiology, Washington, D.C. (1977), p. 1977.

12) H. J. Doddema and G. D. Vogels, Appl. Environ. Microbiol., 36, 752 (1978).

13) N. Blin and B. W. Stafford, Nucl. Acid Res., 3, 2303 (1976).

14) C. L. Schildkraut, J. Marmur, and P. Doty, J Mol. Biol., 4, 430 (1962).

15) E. Conway de Macario, A. J. Macario, and M. J. Wolin, J. Bacteriol., 149, 320 (1982).

16) D. J. Kushner, Adv. Appl. Microbiol., 10, 73 (1968).

17) K. R. Sowers and J. G. Ferry, Appl. Environ. Microbiol., 45, 684 (1983). 